\title{
Метод експериментального дослідження повітряних конденсаторів малих холодильних машин і теплових насосів
}

\author{
Л. І. Морозюк, В. В. Соколовська, С. В. Гайдук, А. В. Мошкатюк \\ Одеська національна академія харчових технологій, вул. Канатна,112, м. Одеса, 65039, Україна
}

\begin{abstract}
Джерелом зниження ефективності теплообмінного апарату в процесі експлуатації є відклади. Проблеми відкладів на поверхнях теплообмінних апаратів віднесено до “невирішених". В роботі наведено спосіб експериментального дослідження повітряного конденсатора з реальними відкладами та модельованими решіткамиімітаторами на зовнішній поверхні Доведено, щчо головним критерієм для аналізу відкладів є його структура.
\end{abstract}

Ключові слова: Повітряний конденсатор; Експериментальний стенд; Теплообмінна поверхня; Відклади

\section{1. Вступ}

Різноманітні процеси теплообміну в холодильних установках вимагають різної кількості конструкцій теплообмінних апаратів. Кожен теплообмінний апарат в складі установки має забезпечувати надійне поєднання теплової ефективності, зручності експлуатації з малими капітальними та експлуатаційними витратами. Теплообмінні апарати є частиною комерційного обладнання, тому питання капітальних і експлуатаційних витрат як на сам апарат, так і на всю установку є для споживача актуальними.

Експлуатація пов'язана з ризиками, які суттєво впливають на основні характеристики теплообмінника. Одним 3 джерел негативної трансформації процесів є поява і зростання твердих відкладів на теплообмінної поверхні апарату, що призводить до зниження ефективності теплообміну і скорочує «життєвий цикл» апарата.

Повітряні конденсатори широко використовують в системах комерційного призначення та в регіонах 3 обмеженими водними ресурсами вони є єдиним варіантом серед систем відведення тепла.

Перешкоду ефективній роботі повітряного конденсатора створюють зовнішні впливи, наприклад, підвищений вміст газів, пилу, кіптяви, пуху у зовнішньому повітрі і т.і. Результат - наростання на зовнішній поверхні твердих відкладів, які приводять до підвищення шумів в установці, погіршення теплообміну, підвищення енергоспоживання і порушення стабільної роботи всієї системи.

Існуючі дослідження реальних умов роботи повітряних конденсаторів не містять універсальних інженерних методик розрахунку, які дозволили б спрогнозувати на стадії проектування реальні умови експлуатації.
Отже, актуальними є подальші експериментальні дослідження процесів забруднення повітряних конденсаторів. Їх результати доповнять світову експериментальну базу даних аналізу твердих відкладів, допоможуть розробити способи контролю та усунення твердих відкладів і наблизитись до вирішення «невирішеної проблеми» забруднень [1].

\section{2. Аналіз літературних даних та постановка проблеми}

Проблема зовнішніх відкладів у повітряних теплообмінних апаратах є неминучою в процесі експлуатації. Відклади призводять до зменшення коефіцієнта теплопередавання апарату, оскільки теплопровідність речовини забруднення менша за теплопровідності матеріалів теплообмінної поверхні, що створює додатковий термічний опір. Відклади також створюють додатковий аеродинамічний опір руху потоку повітря, що призводить до зменшення витрати повітря, до погіршення відведення тепла і збільшення енергоспоживання вентиляторів.

У стандартах TEMA [2]. описано різні типи механізмів відкладів.

Для повітряних конденсаторів характерні такі види відкладів [3]: біовідклади, відкладення частинок нагару, тверді механічні відклади. Найбільш поширеними видами твердих відкладів є пух і пил, причому пух $є$ активатором механічних відкладень.

Вплив відкладів з боку повітря на продуктивність різних типів теплообмінників було досліджено багатьма авторами як методами математичного моделювання, так і експериментальними шляхами.

В роботі [10] досліджувалися різні види несправностей кондиціонерів, розміщених на даху будівель. 
При забрудненнях 56\% фронтальної частини конденсатора ефективність системи знизилася на 17,9\% за рахунок збільшення тиску конденсації.

В роботі [11] досліджено вплив відкладів у вигляді пилу в компактних теплообмінниках. Було встановлено, що коефіцієнт теплопередавання при напиленні на поверхню теплообміну 8,3 кг пилу знижується на 18\%. На жаль, в роботі немає інформації про габаритні характеристик теплообмінника.

В роботі [12] було досліджено вплив відкладання пилу на теплообмінних поверхнях випарників кондиціонерів різних розмірів 3 різними типами фільтрів. Представлені математичні моделі трьох типів кондиціонера і процесів, що в них відбуваються. Наведено висновок про зменшення холодопродуктивності та збільшення потужності системи, за рахунок зменшення швидкості потоку повітря. Аналогічно забруднення впливає на потужність вентиляторів випарника.

Робота [13] містить експериментальне дослідження впливу забруднення на роботу повітряних теплообмінників побутового кондиціонера. Відклади було зібрано з випарників, виведених з експлуатації. Напилення на теплообмінних поверхнях здійснювалося послідовно у певній масі. Дослідники прийшли до висновку, що процес відкладення залежить від швидкості повітря. Збільшення швидкості повітря зменшує швидкість відкладення. Було встановлено, що відклади на зовнішній теплообмінної поверхні змійовика являють собою суміш пилу і волокон. Вони нерівномірно розподіляються по поверхні і зменшуються в напрямку від зовнішньої поверхні до першого ряду трубок. 3 внутрішньої сторони відклади рівномірно розподіляються на ребрах.

В роботі [14] досліджені пластинчасті і мікроканальні теплообмінники в умовах забруднень. Теплообмінники були протестовані з двома різними типами пилу. Ці дослідження показали, що більш схильні до забруднення мікроканальні теплообмінники.
Всі автори робіт стверджують, що відкладення на теплообмінній поверхні залежать від ряду факторів як у самій системі, так і зовнішніх параметрів: геометрії теплообмінної поверхні, продуктивності системи, швидкості руху повітря, типу відкладів, умов експлуатації при сезонних і добових змінах параметрів зовнішнього повітря і т.і.

На підставі огляду технічної інформації в системи необхідно вводити захисні заходи для мінімізації відкладів і витрат на їх ліквідацію.

Результати аналізу забруднень є корисною інформацією для розробки методів інженерних розрахунків, які дозволяють на стадії проектування і в процесі експлуатації контролювати і визначати процес зростання відкладів, тим самим забезпечити згодом стабільність роботи всієї системи.

Метою роботи є проведення експериментальних досліджень повітряного конденсатора 3 реальними відкладами та модельованими пристроями, що імітують реальні відклади на теплообмінній поверхні.

Для досягнення поставленої мети розв'язані такі завдання:

- спроектовано і виготовлено експериментальний стенд;

- проведено випробування конденсатора 3 реальними твердими відкладами;

- проведено випробування 3 решітками-імітаторами відкладів;

- проаналізовано результати проведених експериментів.

\section{3. Експериментальний стенд}

Принципову схему стенду надано на рисунку 1. Стенд являє собою холодильну машину, яка працює за циклом одноступеневого стиснення. Робочою речовиною в машині є R-22.

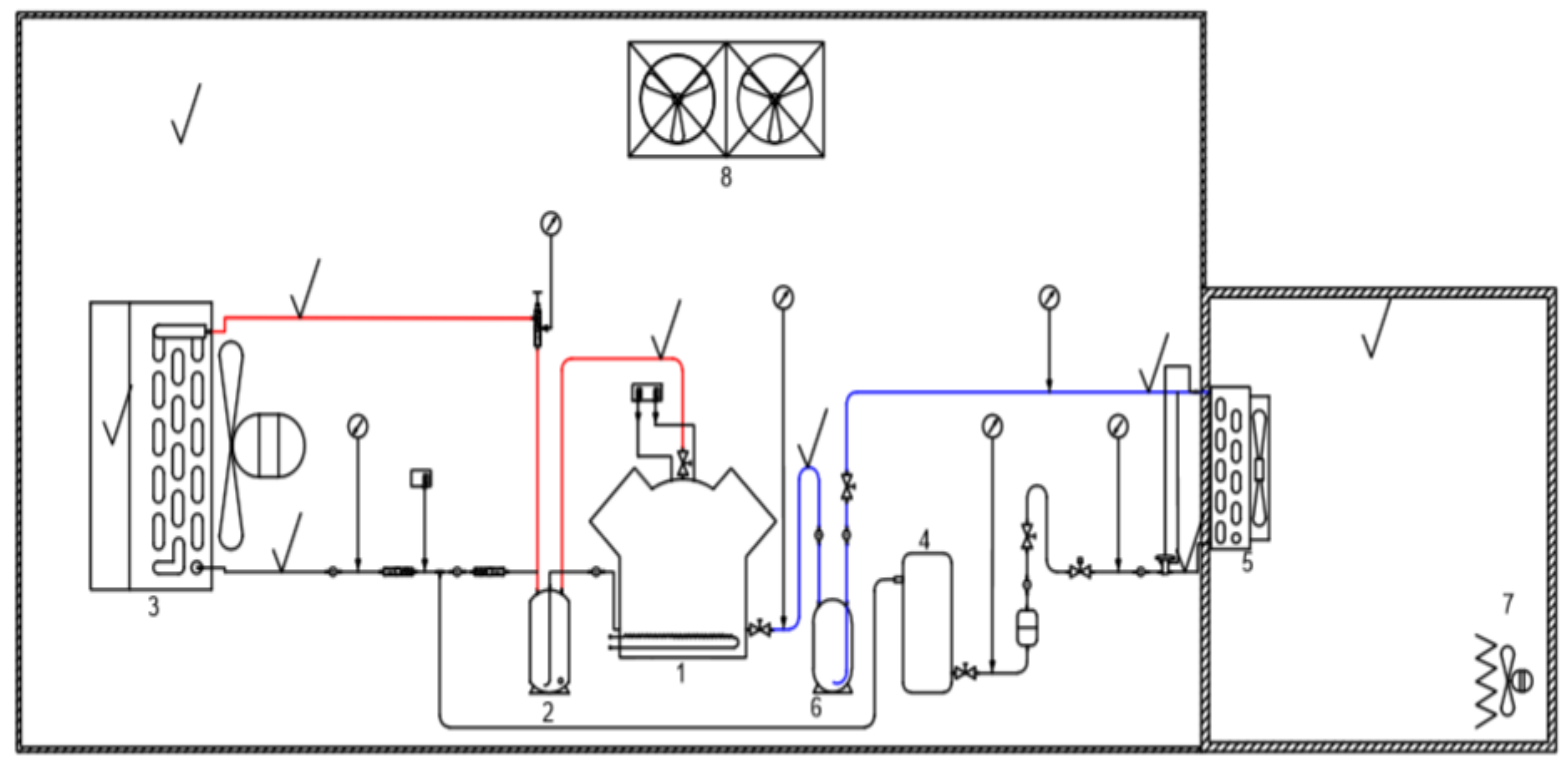

Рисунок 1 - Принципова схема стенду 1-компресор, 2-оливовідділювач, 3-конденсатор, 4- ресивер, 5-повітроохолоджувач, 6-відділювач рідини, 7-електронагрівач, 8-тепловий насос.

Figure 1 - The principal scheme of the stand: 1 - compressor, 2 - oil separator,3 - air condenser, 4 - receiver, 5-air-cooler, 6 - liquid separator, 7 - electric heater, 8 - heat pump. 
Одним 3 елементів стенду $\epsilon$ компресорноконденсаторний агрегат фірми BITZER - марки LH32E/2KES-0.5. Склад агрегату: напівгерметичний поршневий компресор 1, повітряний конденсатор 3, оливовідділювач 2, ресивер 4 і відділювач рідини 6 . Агрегат встановлено у приміщенні, в якому параметри повітря постійні завдяки роботі теплового насосу 8.

Навколо повітряного конденсатора встановлений короб, що забезпечує вирівнювання потоку повітря на вході в конденсатор.

Холодильна машина забезпечує низьку температуру в камері за допомогою повітроохолоджувача 5. Теплове навантаження здійснюється за допомогою електронагрівача 7.

Стенд обладнаний контрольно-вимірюваль-ними приладами для визначення параметрів повітря та робочої речовини. Температури вимірюються за допомогою холодильного контролера марки eliwell id 974 з використанням ПТС датчиків 3 класом точності 0,10. Розміщення датчиків температур показано на рисунку 1. Швидкість потоку повітря на вході в конденсатор вимірюється портативним цифровим анемометром 3 похибкою $+0,01$ м/с. Напруга і сила струму вимірюється цифровим мультиметром UT201 з струмовою петлею. Тиск на всмоктуванні і нагнітанні в компресор вимірюється манометрами низького і високого тиску, підключених до штатних вентилів на компресорі.

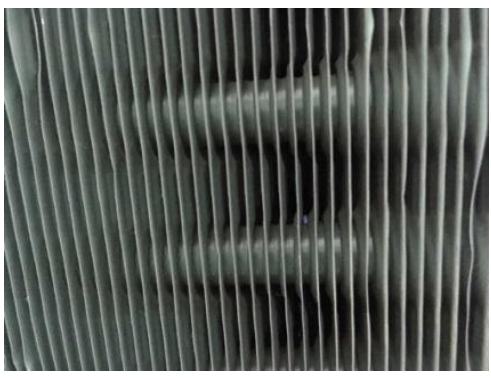

a)

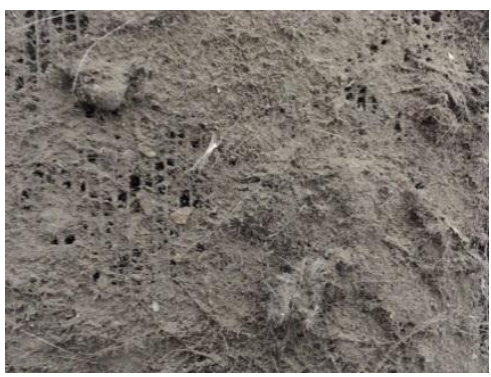

c)

\section{4. Методи експериментального дослідження}

Об'єктом дослідження є повітряний кон-денсатор розмірами $400 \times 400 \times 120$ мм. Теплообмінну поверхню конденсатора виконано з мідних труб, розміщених у шаховому порядку 3 кроком $25 \times 25 \mathrm{Mm}, 3$ пластинчастими алюмінієвими ребрами завтовшки 1,1 мм, 3 кроком між ребрами 2,3 мм. Циркуляцію повітря забезпечує вісьовий вентилятор.

Для проведення випробувань було зібрано пил з 4х діючих конденсаторів холодильних машин комерційного призначення ідентичних зразку, який досліджується. Конденсатори перебували в однакових умовах експлуатації. Апарати змонтовані на фасадній стороні будівель мінімаркетів, які розміщені на вулицях великої транспортної завантаженості на відстані 20 м від проїжджої частини.

Зібраний матеріал відкладів було зважено та підготовлено для напилення на теплообмінну поверхню конденсатора. Під час підготовки матеріалу і процедури напилення використовувалися рекомендації робіт $[14,15]$.

Експериментальні дослідження проводилися у декілька етапів. На першому етапі випробування проходили $з$ чистою поверхнею конденсатора. Далі 300 г відкладу було розділено на три частини. Пил розпоро-

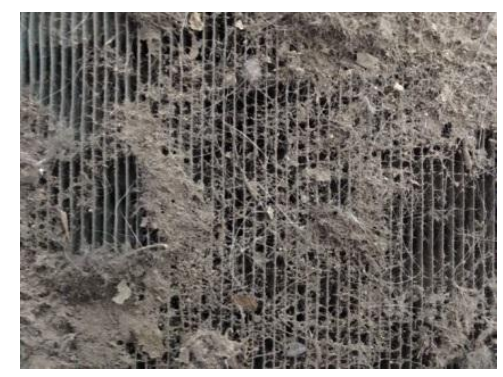

b)

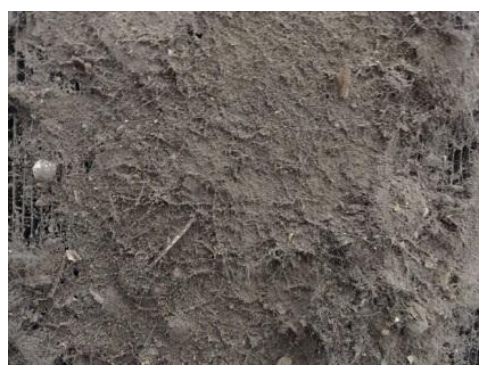

d)

Рисунок 2 - Теплообмінна поверхня конденсатора під час проведення експерименту a) чиста поверхня; b) напилення 100 г твердого відкладення;

c) напилення 200 г твердого відкладення; d) напилення 300 г твердого відкладення

Figure 2 - Heat-exchanged condenser surface during the experiment

a) the surface is clean; $b$ ) the surface spraying of the $100 \mathrm{~g}$ solid fouling;

c) the surface spraying of the $200 \mathrm{~g}$ solid fouling; d) the surface spraying of the $300 \mathrm{~g}$ solid fouling.

шувався окремими порціями як дрібнодисперсне середовище в суміші з водою. На рисунку 2 надана забруднена теплообмінна поверхня конденсатора 3 різним ступенем забруднення.
Випробування здійснено $з$ усіма забрудненими поверхнями, визначалися характеристики і параметри роботи холодильної машини. 
Забруднення відтворювали реальні умови роботи повітряних конденсаторів.

Альтернативним способом випробування запропоновано штучне моделювання аеродинамічного опору потоку повітря. Дійсне забруднення замінено імітатором-решіткою із змінним живим перетином (рисунок 3). Решітка являє собою плоскість 3 горизонтальними отворами, крізь які має рухатись повітря. Загальний живий перетин кожної решітки становить від 10 до 75\% дійсного живого перетину чистої поверхні апарату. Решітку встановлено на вході повітря в теплообмінний апарат.

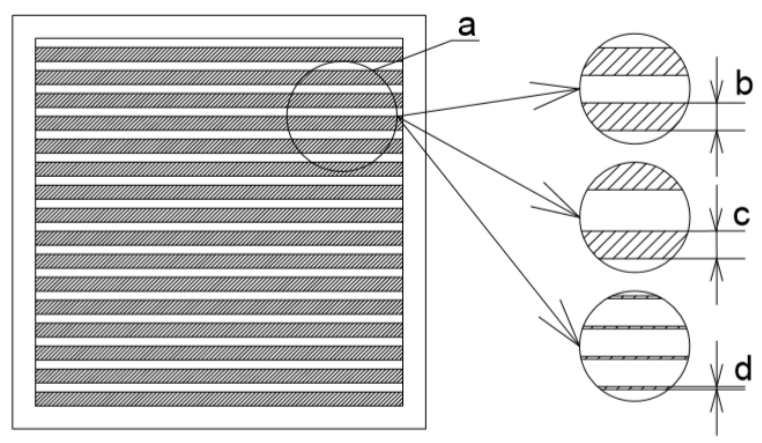

Рисунок 3 - Конструкція імітаційних решіток а) 75\% відкритого живого перетину; b) 50\% відкритого живого перетину; с) $25 \%$ відкритого живого перетину; d) 10\% відкритого живого перетину

Figure 3 - Constructions of the imitation grille a) $75 \%$ open free area of the grille; b) $50 \%$ open free area of the grille; c) $25 \%$ open free area of the grille; d) $10 \%$ open free area of the grille

Випробування здійснено з чотирма решітками, визначалися характеристики і параметри роботи холодильної машини.

\section{5. Обробка даних і результати випробувань повітряного конденсатора}

За результатами прямих вимірювань визначались непрямі, такі як холодопродуктивність машини, теплове навантаження на конденсатор, потужності компресора і вентилятора конденсатора енергетична ефективність машини.

Водночас з обробкою експериментальних даних, використовуючи прямі виміри були проведені варіантні теплові розрахунки характеристик холодильної машини в різних режимах роботи. Коефіцієнт перетворення дійсного циклу холодильної машини визначався як:

$$
C O P=Q_{o} / \sum N_{\partial \beta},
$$

3 графіка видно, що одна і та ж енергетична ефективність холодильної машини досягається при певному відношенні дійсного забруднення до модельованого.

В інтервалах $0 \ldots 100$ гр дійсного забруднення та $0 . .25 \%$ модельованого СОР змінюється однаково з 2,6 до 3,3 . де $\sum N_{\partial \varepsilon}$ - сумарна потужність двигунів компресора i вентилятора конденсатора

$$
\sum N_{\partial в}=U \cdot\left(I_{1}+I_{2}+I_{2}\right)+U \cdot I^{в н}:
$$

$Q_{0}$ - холодопродуктивність компресора

$$
Q_{0}=M_{a} \cdot\left(h_{1}-h_{3}\right),
$$

де $h$ - ентальпії в відповідних точках циклу;

$M_{a}$ - масова витрата робочої речовини, яку визначимо з енергетичного балансу повітряного конденсатора:

$$
M_{a} \cdot\left(h_{2}-h_{3}\right)=M_{603} \cdot c_{p} \cdot\left(t_{6 b x}^{603}-t_{6 x}^{603}\right)
$$

де $t_{\text {вих }}^{\text {пов }}$ - температура виходу повітря з конденсатора;

$t_{\text {вx }}^{\text {nов }}$ - температура входу повітря в конденсатор;

$c_{p}$ - теплоємність повітря;

$M_{\text {пов }}$ - масова витрата повітря.

Масова витрата повітря становить:

$$
M_{\text {пов }}=F_{\mathscr{C}-n} \cdot v_{\text {пов }} / \rho_{\text {пов }},
$$

де $F_{ж-n}-$ площа живого перетину повітряного конденсатора

$v_{n o в}-$ середня швидкість повітря через конденсатор;

$\rho_{\text {пов }}-$ густина повітря.

Результати розрахунку СОР в залежності від ступеня забруднення дійсними відкладами та зміни живого перетину решітки імітатора представлені в графічному вигляді на рисунку 4.

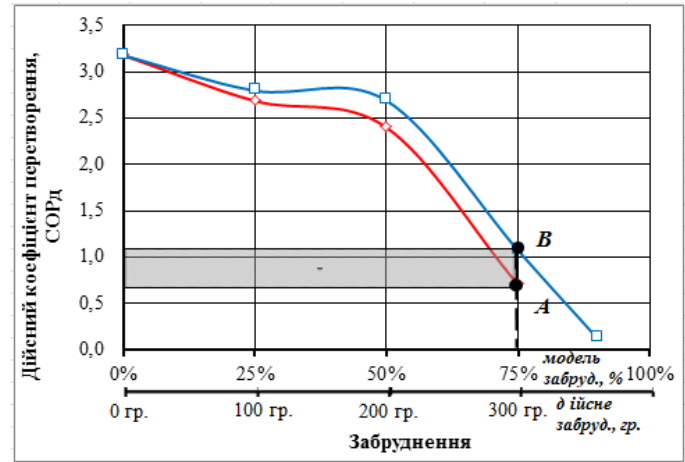

Рисунок 4 - Коефіиієнт перетворення дійсного циклу в залежності від типу забруднень дійсних $i$ модельованих

Figure 4 - The coefficient of performance of the actual cycle depending on the type of the actual and simulated fouling

$$
\checkmark-\square
$$

За зростанням дійсних відкладів і модельованого аеродинамічного опору решітки-імітатора спостерігаються розбіжності в характерах зміни СОР.

Наприклад, при наявності 300 г твердих відкладів (точка А) та 75\% живого перетину решітки-імітатора (точка В) розбіжності СОР складають до 10\%. Це 
пов’язано з відмінністю фізичних принципів побудови опору потоку повітря.

Подальші експериментальні дослідження пов'язані з визначенням впливу відкладів на теплопередавання в повітряному конденсаторі.

На підставі прямих вимірів визначалася густина теплового потоку, коефіцієнт теплопередавання і теплове навантаження на конденсатор. При цьому розрахунковий еквівалентний діаметр приймався постійною

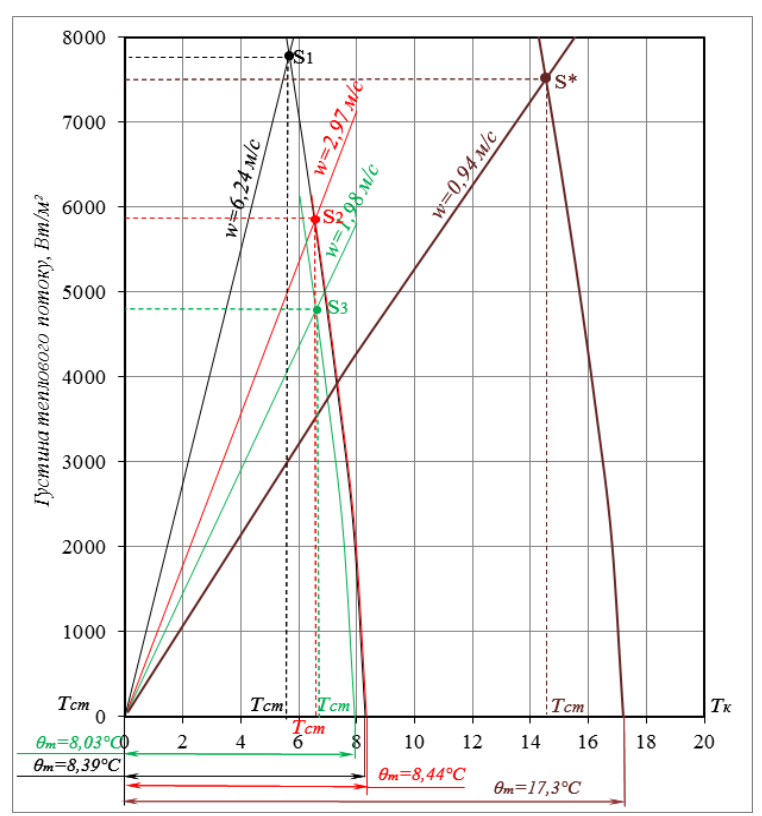

Рисунок 5 - Графоаналітичний метод визначення густини теплового потоку з дійсним забрудненням

Figure 5 - The graph-analytical method for the density of heat flow rate determining with actual fouling

Результати розрахунків зведені в таблицю 1. Розрахунки показали, що збіжність результатів експериментів спостерігається в інтервалі 100..200 г дійсних відкладів та 50...75\% форми решітки-імітатора.

Подальше зменшення живого перетину решіткиімітатора призводить до падіння густини теплового потоку, що повністю відповідає класичному теплопередаванню [11].

Зовсім інший характер зміни густини теплового потоку спостерігається при збільшенні дійсних відкладів. Розглянемо режим повного забруднення конденса- величиною. Розрахунок густини теплового потоку здійснювався графоаналітичним методом за принципом класичних методик розрахунків повітряних конденсаторів $[10,11]$. Густина теплового потоку в залежності від температурного напору в апараті, змінної температури конденсації і змінній витраті повітря представлені на рисунку 5. для двох моделей відкладів: рисунок 5а 3 дійсним забрудненням, рисунок 56 за наявністю решіток-імітаторів.

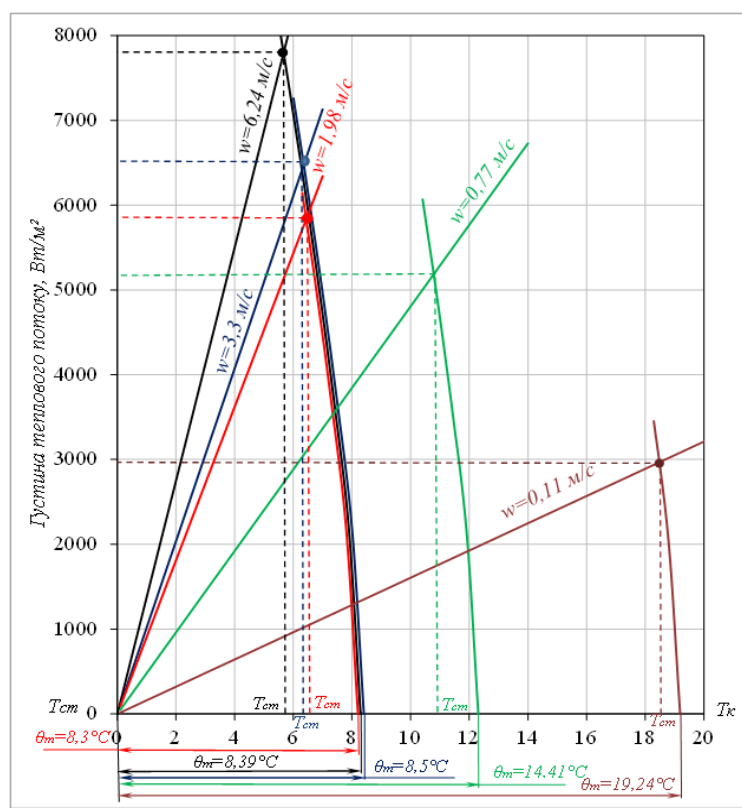

Рисунок 6 - Графоаналітичний метод визначення густини теплового потоку за наявністю решіток-імітаторів

Figure 6 - The graph-analytical method for the density of heat flow rate determining with the imittion grilles

тора (300 г відкладів, точка 3*, рисунок 5б).

Спостерігається збільшення густини теплового потоку. При цьому зменшується швидкість повітря і збільшується температурний напір в апараті. Таке аномальне явище може бути описане 3 позицій теорії пористих структур [12].

3 рисунку 5б видно, що густина теплового потоку повністю забрудненого конденсатора близька до густини теплового потоку в чистому конденсаторі (точка С), що пов'язано зі збільшенням температурного напору в апараті.

Таблиця 1 - Результат впливу відкладів на теплопередавання в повітряному конденсаторі

\begin{tabular}{|c|c|c|c|}
\hline $\begin{array}{c}\text { Ступінь забруднення, } \\
\text { ма форма решітки-імітатора }\end{array}$ & $\begin{array}{c}\text { Густина } \\
\text { теплового потоку, } \\
q_{\text {вн }}, \mathrm{BT} / \mathrm{M}^{2}\end{array}$ & $\begin{array}{c}\text { Теплове } \\
\text { навантаження на конденсатор } \\
Q_{k}, \text { кВт }\end{array}$ & $\begin{array}{c}\text { Загальний коефіцієнт } \\
\text { теплопередавання апарату } \\
k, B m / \mathrm{m}^{2} \cdot K\end{array}$ \\
\hline Чиста поверхня & 7900 & 3810 & 163,9 \\
\hline 100 г відкладів & 5900 & 2846 & 90,49 \\
\hline 200 г відкладів & 4800 & 2315 & 30,95 \\
\hline 300 г відкладів & 7500 & 3617 & 119,8 \\
\hline $75 \%$ & 6600 & 3183 & 109,1 \\
\hline $50 \%$ & 5800 & 2797 & 38,75 \\
\hline $25 \%$ & 5200 & 2508 & 8,328 \\
\hline
\end{tabular}


Рисунки 7-8 ілюструють характер зміни основних характеристик конденсатора: густини теплового потоку і коефіцієнта теплопередавання від типу забруднень.

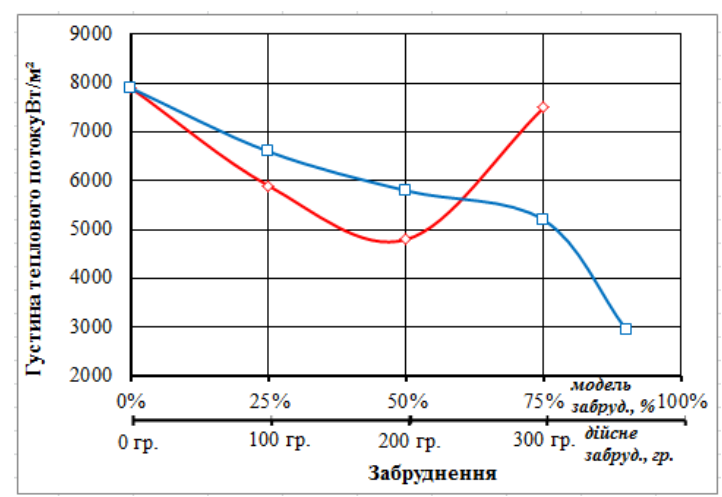

Рисунок 7 - Густина теплового потоку в залежності від типу забруднень $\leadsto$. дійсних і модельованих $\square-\square$. Figure 7 - The heat flow rate depending on the type of actual and simulated fouling

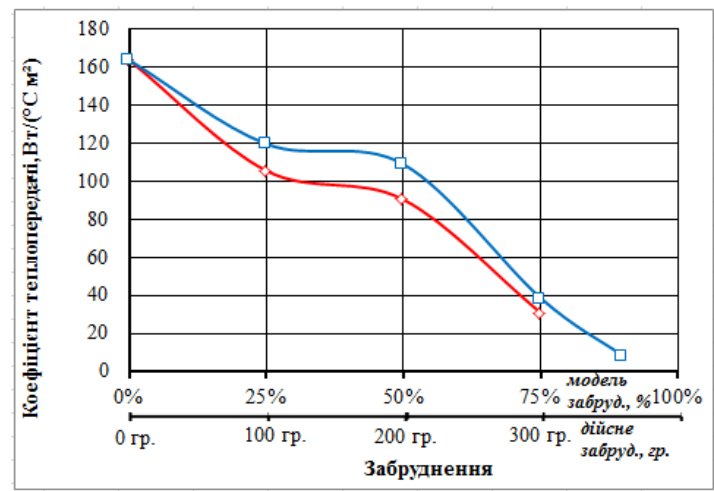

Рисунок 8 - Коефіиієнт теплопередавання в залежності від типу забруднень $\checkmark$ „діиссих і модельованих $\square-$.

Figure 8 - The heat transfer coefficient depending on the type of actual and simulated fouling

Характери зміни коефіцієнта теплопередавання за відповідними аргументами мають однаковий вигляд (рисунок 7). За зростанням дійсних відкладів і зменшенням живого перетину решітки-імітатора коефіцієнт теплопередавання різко падає. Але фізика процесу погіршення теплопередавання абсолютно різна.

При наявності дійсних твердих відкладів в апараті триває рух повітря крізь структуру відкладів, швидкість повітря падає, а повітря значно підігрівається.

Інша справа відбувається в решітках-імітато- рах. Повітря в решітці рухається у вільному просторі. Матеріал імітатора не прозорий для проходу повітря, відповідно підігріву повітря не відбувається.

Третім напрямом експерименту є визначення характеру зміни втрати тиску в конденсаторі в залежності від ступеня забруднень. Прямим вимірам піддавалася швидкість повітря.

За результатами розрахунків втрата тиску збільшується з зростанням забруднень (рисунок 9).

При досягненні певної величини відкладів (точка F1, F2) втрата тиску зменшується. Це спостерігається при повному забруднені живого перетину, коли основ- ний потік повітря практично не проходить через нього і ежектує торцевий потік повітря навколишнього середовища. У результаті відбувається перерозподіл між об'ємною витратою повітря і втратою тиску.

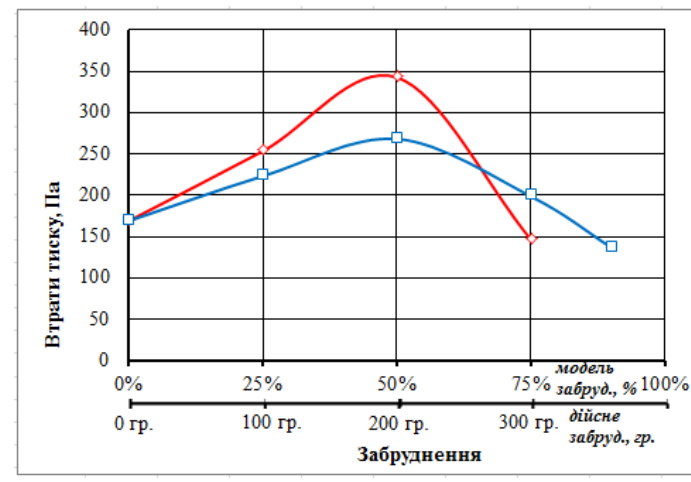

Рисунок 9 - Залежність втрати тиску в конденсаторі від типу забруднень $\checkmark-$ дійсних і модельованих $\square-$

Figure 9 - The condenser pressure loss depending on the type of actual and simulated fouling

Проведені експериментальні дослідження конденсатора показали, що навіть при повному забруднені конденсатор залишається працездатним, а основне енергетичне навантаження лягає на компресор.

\section{6. Висновки}

Метод експериментального дослідження, побудований на використанні модельованих забруднень (решіток-імітаторів), може бути використаним в певних межах. Такі межі встановлює структура забруднення. Вибір конструкції імітаторів (зміна форми решітки, матеріалів решітки, тощо) може здійснюватися тільки при наявності інформації про структуру забруднень.

Подібний експеримент може бути проведеним на конденсаторі дійсної холодильної машини яка знаходиться в постійній експлуатації, оскільки додаткові елементи є допоміжними і не впливають на термодинамічний цикл машини.

Доведено, що головним критерієм для аналізу відкладу є його структура.

\section{Література}

1. Mostafa, M. Awad. Fouling of heat transfer surfaces, heat transfer - theoretical analysis, experimental snvestigations and industrial systems [Text] / prof. Aziz Belmiloudi (Ed.). - 2011. - ISBN: 978-953-307-226-5, InTech. Available from: http://www.intechopen.com/books/heattransfer-theoretical-analysis-experimentalinvestigationsand-industrial-systems/fouling-of-heat-transfer-surface. 2. Standards of the tubular exchanger manufacturers association [Text]: 9th edn. TEMA Inc. - New York, 2007. 3. Sarfraz Omer, Bach Christian. A literature review on heat exchanger air side fouling in heating, ventilation and airconditioning (HVAC) applications [Text] / Omer Sarfraz, Christian Bach // International refrigeration and air conditioning conference. - Purdue, USA, 2016. 
4. Breuker, M. S., Braun, J. E. Common faults and their impacts for rooftop air conditioners. HVAC and R Research / M.S. Breuker, J.E. Braun. - 1998. - 4(3). - p. 303-317.

5. Lankinen, R., Suihkonen, J., Sarkomaa, P. The effect of air side fouling on thermal-hydraulic characteristics of a compact heat exchanger [Text] / R. Lankinen, J. Suihkonen, P. Sarkomaa // International Journal of Energy Research. - 2003. - 27(4). - p. 349-361.

6. Yang, L., Braun, J.E., Groll, E.A. The role of filtration in maintaining clean heat exchanger coils [Text] / L. Yang, J.E. Braun, E.A. Groll. // Final report ARTI-21CR/61140050-01, air-conditioning and refrigeration technology institute (ARTI). - 2004.

7. Ali, A. H., \& Ismail, I. M. Evaporator air-side fouling: effect on performance of room air conditioners and impact on indoor air quality [Text] / A. H. Ali, I. M. Ismail // HVAC\&R Research. - 2008. - 14(2). - p. 209-219.

8. Ian H. Bell, Eckhard A. Groll. Experimental comparison of the impact of air-side particulate fouling on the thermo-hydraulic performance of microchannel and platefin heat exchangers [Text]/ Ian H. Bell, Eckhard A. Groll //
International Refrigeration and Air Conditioning conference. - Purdue, USA, 2010.

9. Bell, I., Groll, E., König, H. Experimental analysis of the effects of particulate fouling on heat exchanger heat transfer and air side pressure drop for a hybrid dry cooler [Text] / I. Bell, E. Groll, H. König // Heat Transfer Engineering In Press. -2009.

10. Кошкин Н.Н. Тепловые конструктивные расчеты холодильных машин [Текст] / Н.Н. Кошкин. - Л.: Машиностроение, 1976. - 463c.

11. Данилова Г.Н. Теплообменные аппараты холодильных установок [Текст] / Г.Н. Данилова [и др.]. - Л.: Машиностроение, 1986.- 303 с.

12. Morosuk T. Porous media theory as basis for model of fouling layers formation in heat exchangers. Condenser and evaporator of refrigeration machines and heat pumps [Text] / T. Morosuk // In: Emerging Technologies and Techniques in Porous Media, Eds. Ingham, D.B. et al. - Kluwer Chapter 32. - Academic Published. - 2003. - p. 491-507.

\title{
Method of Experimental Investigation of Air-Cooled Condensers for Small Refrigeration Machines and Heat Pumps
}

\author{
L. I. Morosuk, V. V. Sokolovska, S. V. Gaiduk, A. V. Moshkatuk \\ Odessa National Academy of Food Technologies, 112 Kanatnaia str., Odessa, 65039, Ukraine
}

\begin{abstract}
Air-cooled condensers are widely used in commercial refrigeration machines and heat pumps. In the geographical regions with limiter water resources, the application of the air-cooled condensers is the only option for the systems for removing heat of the condensation process. The effectiveness of the air-cooled condensers depends on the internal factors such as increased amount of gases as well as external factors such as solid fouling. The result of growing the thickness of solid fouling is the following: increasing the sough level, decreasing the heat transfer coefficient, increasing the energy consumption and non-stable operation of the entire system. The analysis of the solid fouling is the useful information that should be included to the engineering calculations. It will help to estimate the operation parameters of the air-cooled condensers during the design as well as stability of operation of the refrigeration machine or heat pump. In the paper the experimental data of the air-cooled condensers with real solid fouling have been reported. The aircooled condenser is a component of one-stage refrigeration machine (BITZER, LH32E/2KES-0.5.) with R22 as the working fluid. The refrigeration machine was installed in a thermostatic room. The refrigeration capacity was imitated using an electrical heater. The experiment has been conducted for clean surface of the condenser as well for different levels of solid fouling and aerodynamic resistance modeled artificially. Using the obtained experimental data, the value of the refrigeration capacity, condensation heat rate, and power supplied for compressor and fan have been determined at different thickness of solid fouling and aerodynamic resistance. The experimental data showed that condenser is capable to operate at any thickness of solid fouling, and the compensation is the power supplied to the compressor. It was proven that the main criteria for the analysis is the structure of solid fouling.
\end{abstract}

Keywords: Air Condenser; Experimental Stand; Heat Exchange Surface; Fouling.

\section{References}

1. Mostafa, M. Awad (2011). Fouling of heat transfer surfaces, heat transfer - theoretical analysis, experimental snvestigations and industrial systems, prof. Aziz Belmiloudi (Ed.), ISBN: 978-953-307-226-5, InTech.

2. Standards of the tubular exchanger manufacturers Association (2007). 9th edn., TEMA Inc, New York.

3. Omer Sarfraz, Christian Bach. (2016). A Literature Review On Heat Exchanger Air Side Fouling In Heating,
Ventilation And Airconditioning (HVAC) Applications. International refrigeration and air conditioning conference, Purdue, USA.

4. Breuker, M. S., Braun, J. E. (1998). Common faults and their impacts for rooftop air conditioners. HVAC\&R Research, 4 (3), 303-318.

DOI: https://doi.org/10.1080/10789669.1998.10391406

5. Lankinen, R., Suihkonen, J., Sarkomaa, P. (2003). The effect of air side fouling on thermal-hydraulic characteristics of a compact heat exchanger. Int. J. Energy Res., 
27 (4), 349-361. DOI: https://doi.org/10.1002/er.880

6. Yang, L., Braun, J. E., Groll, E. A. (2004). The role of filtration in maintaining clean heat exchanger coils. Final Report ARTI-21CR/611-40050-01, Air-Conditioning and Refrigeration Technology Institute (ARTI).

7. Ali, A. H., Ismail, I. M. (2008). Evaporator air-side fouling: effect on performance of room air conditioners and impact on indoor air quality. HVAC\&R Research, 14(2), 209-219.

DOI: https://doi.org/10.1080/10789669.2008.10391004

8. Ian H. Bell, Eckhard A. Groll. (2010). Experimental comparison of the impact of air-side particulate fouling on the thermo-hydraulic performance of microchannel and plate-fin heat exchangers. International Refrigeration and Air Conditioning conference, Purdue, USA.

9. Bell, I., Groll, E., König, H. (2011). Experimental analysis of the effects of particulate fouling on heat exchanger heat transfer and air side pressure drop for a hybrid dry cooler. Heat Transfer Engineering, 32(3-4), 264-271. DOI: https://doi.org/10.1080/01457632.2010.495618

10. Koshkin, N. N. (1976). Teplovye konstruktivnye raschety kholodilnykh mashin. L.: Mashinostroenie, 463. (in Russian)

11. Danilova G. N. (1986). Teploobmennye apparaty kholodilnykh ustanovok. L.: Mashinostroenie, 303. (in Russian)

12. Morosuk T. (2003). Porous media theory as basis for model of fouling layers formation in heat exchangers. Condenser and evaporator of refrigeration machines and heat pumps. In: Emerging Technologies and Techniques in Porous Media, Eds. Ingham, D.B. et al., Kluwer Chapter 32, Academic Published, 491-507. 